\title{
An Empirical Examination of the Educational Impact of Text Message-Induced Task Switching in the Classroom: Educational Implications and Strategies to Enhance Learning
}

\section{Un Estudio Empírico del Efecto de los Cambios de Tarea en el Aula Inducidos por los Mensajes de Texto: Implicaciones para la Enseñanza y Estrategias para la Mejora del Aprendizaje}

\author{
Larry D. Rosen, Alex F. Lim, L. Mark Carrier, and Nancy A. Cheever \\ California State University, Domínguez Hills, USA
}

\begin{abstract}
Today's Net Generation university students multitask more than any prior generation, primarily using electronic communication tools (Carrier et al., 2009). In addition, studies report that many students text during class (Tindell \& Bohlander, 2011). This research examines the impact of receiving and sending text messages during a classroom lecture. Recent laboratory research (Ophir, et al., 2009) reported that multitasking impaired performance, particularly among heavy multitaskers. Further, experimental research has shown that "technologically induced" interruptions can be disruptive, causing increased errors and decreased performance (Monk, et al., 2008). This study is the first to experimentally examine the direct impact of text message interruptions on memory recall in a classroom environment. Participants viewed a 30-minute videotaped lecture during which they were interrupted by receiving text messages requiring responses. Participants in four classrooms were randomly assigned to three groups receiving no text messages, four text messages or eight text messages. Based on the actual number of texts received and sentincluding those not sent by the experimenter-three comparison groups were defined: No/Low Texting Interruption (zero to 7 text messages sent and received), Moderate Texting Interruption (eight to 15 texts), and High Texting Interruption (16 or more texts). Following the videotaped lecture, a recall test assessed the impact of text message interruptions on memory. In addition, participants were asked about their typical monthly texting and their attitudes toward classroom texting behaviors. Results indicated that the High Texting group scored significantly worse $(10.6 \%$ lower $)$ than the No/Low Texting Interruption group although there was no significant difference between No/Low Texting Interruption and Moderate Texting Interruption group nor was there a significant difference between the Moderate Texting Interruption group and the High Texting Interruption group. In addition, while nearly three fourths of the participants felt that receiving and sending text messages during class was disruptive to learning, $40 \%$ felt it was acceptable to text in class. Results also indicated that those participants who received and sent more words in their texts performed worse on the test although this was moderated by the elapsed time between receiving (or sending) a text with longer delays resulting in better performance. The results of these studies are discussed in terms of Salvucci et al.'s (2009) Unified Theory of the
\end{abstract}

Correspondence on this article should be sent to Lary D. Rosen, e.mail: lrosen@csudh.edu 
Multitasking Continuum plus the potential use of metacognitive strategies when faced with potentially disruptive multitasking. Educational implications are highlighted and strategies outlined for maximizing performance in media-rich multitasking environments.

Keywords: metacognition, text messaging, multitasking, interruption, threaded cognition, memory-for-goals, ACT-R Theory, education.

Resumen. Comparando con las generaciones anteriores, la actual generación que ahora cursan estudios universitarios pueden ser denominados generación Internet y generación 'multitarea', principalmente en lo que se refiere al uso que estos hacen de las herramientas de comunicación electrónicas (Carrier et al., 2009). Además, existen estudios que demuestran que muchos alumnos envían mensajes de texto durante sus clases (Tindell \& Bohlander, 2011). Estudios recientes llevados a cabo en laboratorios (Ophir, et al., 2009) han constatado que el efectuar múltiples tareas a la vez perjudica el rendimiento, sobre todo entre los que más tareas llevan a cabo. Además, otras investigaciones experimentales han mostrado que las interrupciones inducidas por la tecnología son especialmente perjudiciales, provocando errores y un rendimiento menor (Monk, et al., 2008). Esta investigación estudió el efecto de enviar y recibir SMS durante una clase magistral. El presente estudio es el primero en abordar de forma experimental el efecto de los mensajes de texto sobre la memoria en el contexto del aula. Los participantes asistieron a una clase de 30 minutos grabada previamente en vídeo. Mientras tanto, se les enviaba a los participantes vía SMS preguntas que requerían respuestas. Los participantes estaban distribuidos entre cuatro aulas y divididos, dentro de cada aula, y de forma aleatoria, en tres grupos: participantes que no recibieron ningún SMS; participantes que recibieron cuatro SMS; y participantes que recibieron ocho SMS. Según el número de mensajes recibidos y enviados -incluidos los que no fueron enviados por el investigador- se definieron tres grupos de comparación: cero/bajo nivel de interrupciones (entre cero y siete mensajes enviados y recibidos); nivel moderado de interrupciones (de 8 a 15 mensajes); y nivel alto de interrupciones (16 o más). Después de ver la clase grabada, se evaluó mediante una prueba de memoria el efecto de las interrupciones sobre la memoria. Además, los participantes contestaron preguntas sobre su uso mensual de los mensajes de texto, y sus actitudes hacia el envío de SMS durante clase. Los resultados indicaron que el grupo con alto nivel de interrupciones obtuvieron puntuaciones más bajas (un $10.6 \%$ más bajas) que el grupo con cero o bajo nivel de interrupciones, de forma significativa. Sin embargo, no se encontraron diferencias significativas entre el grupo con cero o bajo nivel de interrupciones y el grupo con un nivel moderado de interrupciones, ni tampoco entre este grupo y el grupo con un nivel alto de interrupciones. Además, mientras casi el $75 \%$ piensan que enviar y recibir SMS en clase es perjudicial para el aprendizaje, un $40 \%$ creen que es aceptable hacerlo en clase. Los resultados indicaron también que aquellos participantes que escribieron más palabras en sus mensajes puntuaban más bajo en la prueba de memoria, aunque moderado por el tiempo entre recibir o enviar, con los participantes que más tiempo dejaban entre mensajes puntuando más alto en la prueba. Se analizan estos resultados a la luz de la Teoría Unificada del Continuo Multitarea de Salvucci et al. (2009). También se analizan los usos potenciales de estrategias metacognitivas para enfrentarse a las interrupciones de naturaleza multitarea, y se destacan tanto las implicaciones para la enseñanza como las posibles estrategias para maximizar el rendimiento en situaciones-multitarea y con múltiples medios.

Palabras clave: metacognición, mensajes de texto, multitarea, interrupciones, cognición de tareas simultáneas, memoria de objetivos, Modelo ACT-R, enseñanza. 
According to a recent national study (Zickuhr, 2011) $85 \%$ of Americans ages 18 and older and $95 \%$ of 18- to 34-year-olds own a cell phone. An ongoing national survey of 60,000 phone bills (Nielsen Company, 2011) found that in the beginning of 2007 teens sent and received an average of 435 text messages a month and that by the final quarter of 2010 this number had increased to 3,705 text messages per month. Overall, the Nielsen study found that $66 \%$ of cell phone users send text messages with young adults (1,707 per month) and preteens (1,178 per month) following teens in their burgeoning SMS usage. Further, a recent study by the Pew Internet \& American Life Project (Lenhart, 2010) found that texting is now the most common way that teenagers communicate with their friends with $54 \%$ texting friends followed by $38 \%$ talking on a cell phone, and $33 \%$ talking face-to-face.

Cell phone use has also expanded to the classroom where note passing has been supplanted by texting as surreptitious communication. Tindell and Bohlander (2011) reported that $91 \%$ of college students in their study had sent or received a text message in their university class and $62 \%$ felt texting should be allowed in class if it does not disturb other students. The Pew report (Lenhart, 2010) found that $58 \%$ of cell phone owning teens whose school bans the devices have sent a text message during class; $64 \%$ of those teens have texted in class at least once; and $43 \%$ of all cell phone-toting teens text in class at least once a day. With texting being the typical means of communication for teens and young adults, it is not surprising that students text in class. The question remains whether this impacts learning.

\section{Classroom Interruptions}

Internet-based technologies, communication tools, and other forms of media have made interruptions commonplace. According to Oulasvirta and Saariluoma (2006), interruptions can disrupt the encoding of content and cause difficulty when asked to retrieve the information. In contrast, Monk,
Trafton, and Boehm-Davis (2008) stated that for most people, "dealing with interruptions is not a problem to be overcome as much as it is an inevitable part of life. In fact, the ability to 'multitask' is considered a desirable job skill by many employers, which is not surprising given that, on average, workers shift between tasks every 3 minutes" (p. 299). The present study provides an extension to this field of research by examining how one handles technological interruptions in a real classroom environment.

Personal mobile technologies have proven a difficult transition for educators. On the one hand, schools want to integrate these technologies into the curriculum. However, according to Lenhart, Ling, Campbell and Purcell (2010), "most schools treat the phone as a disruptive force that must be managed and often excluded from the school and the classroom" (p. 7). In the classroom, cell phones, email, instant messaging (IM), and other technology and media compete for attention and can ultimately disrupt the learning process (Wijekumar \& Meidinger, 2005).

Research by Garrett and Danziger (2008) found that multitasking led to a high occurrence of interruptions which may prove problematic for college students attempting to attend to classroom material which, by its nature, requires extensive working memory. Further, recent research (Carrier, Cheever, Rosen, Benitez, \& Chang, 2009) demonstrated that while multitasking is common among people of all ages, it is most prominent among members of the Net Generation-those born between 1980 and 1989 (Rosen, Carrier \& Cheever, 2010). Carrier et al. (2009) found that across all generations, tasks such as playing video games or reading a book, which involve more working memory, provide more multitasking difficulty. According to Carrier, et al. (2009), texting was found to be one of the more difficult tasks to multitask.

In addition, not only do interruptions impact primary task performance, but studies have shown that interruptions that occur in various modalities have different performance outcomes when it comes to accomplishing the primary task (Ratwani, Andrews, 
Sousk \& Trafton, 2008). Further, Oulasvirta and Saariluoma (2004) stated that it is common for individuals who are studying material to divert their attention to interrupting messages such as e-mails or instant messages which, as they demonstrated in their study, may negatively impact learning. In addition, the increased time required to accomplish a task has been shown to lead to more errors (Ratwani et al., 2008) and greater feelings of stress and anxiety (Gonzales \& Mark, 2004; Ratwani et al., 2008).

A recent study conducted by Ophir, Nass and Wagner (2009) suggests that multitasking is detrimental to performance, particularly for members of the Net Generation who simultaneously use multiple media sources. Ophir et al. (2009) examined chronic heavy media multitaskers compared to light media multitaskers on a battery of tests requiring taskswitching such as identifying whether a number is odd when it is coupled with a letter distractor on the screen. Based on the differences in dual-task performance between groups, Ophir et al. (2009) concluded that "heavy multitaskers are distracted by the multiple streams of media they are consuming or, alternatively, that those who infrequently multitask are more effective at volitionally allocating their attention in the face of distractions" (p. 15585). Although their results were compelling, the study was performed in a laboratory with tasks that may not represent realworld media multitasking environments.

In the workplace, interruptions have also been shown to impact performance by requiring more time to complete an interrupted task. For example, Altmann and Trafton (2004) studied resumption lag, defined as the time interval between the completion of the secondary (interrupting) task and the first action in returning to the primary task, and found substantial resumption lags after being interrupted. In an observational study over a three-day period, Gonzales and Mark (2004) found that computer programmers were interrupted every three minutes while Benbunan-Fich and Truman (2009) found that using laptops during course meetings led to nearly one interruption every two minutes. Parnin and Rugaber (2009) examined 10,000 sessions of 85 computer pro- grammers and found that more than half of resumption lags were five minutes or longer and only one in six were less than one minute. Similarly, Judd and Kennedy (2011) reported that medical students switched tasks every five minutes while studying in the school computer lab. Finally, Czerwinski, Horvitz and Wilhite (2004) showed among their sample of knowledge workers, a weeklong diary revealed that $23 \%$ of interruptions were self-initiated and $23 \%$ of the time interruptions were due to e-mail.

Not only does technology lead to numerous interruptions, but returning to task from those interruptions requires additional time. Mark, Gudith, and Klocke (2008) reported that on average their programmers took more than 25 minutes to return to the original task after interruption. Jackson, Dawson, and Wilson's (2003) study of interruptions in a 500employee British company found that $70 \%$ of emails were responded to within six seconds of arriving and $85 \%$ within two minutes. Upon responding, each e-mail required an average of two minutes of interruption-one minute to respond to the e-mail and another minute of "recovery time."

There is limited research on the impact of memory recall of lecture material with interruptions in a classroom environment. A study by Oulasvirta and Saariluoma (2004) examined the memory effects of interruptive video messages in an undergraduate course and found that when participants diverted their attention to an interrupting message, their memory accuracy decreased by $16 \%$, particularly when the interruptive material was semantically similar to the to-be-learned material. Fried (2008) found that students who used laptops more in class multitasked more, were more distracted and had worse classroom performance. Interestingly, classroom students rated in-class laptop use as more distracting than other students talking in class.

In contrast to previous research demonstrating the detrimental effects of interruptions, Bowman, Levine, Waite and Gendron (2009) demonstrated that in a real-world setting, interruptions may not negatively affect task performance. Bowman et al. (2009) examined instant messages (IMs) as a form 
of interruption during a learning task. Participants were randomly assigned to one of three conditions: a control group received no IMs while reading a passage, a first experimental group received IMs before reading the passage, and a second experimental group received IM interruptions while reading the passage. Upon completion of the task-reading only for the control group and reading plus IM conversation for the two experimental groups-all participants took a memory recall test. Students took significantly longer to read the passage in the second experimental condition than in the other conditions; however, the students' test performance did not differ between all conditions suggesting that they may have consciously dealt with the interruption by spending additional time reading the material following the interruption. Similarly, Fox, Rosen and Crawford (2009) found that IM users during a reading comprehension task required more time to complete the task than those not using IM, yet comprehension scores were unaffected.

Subsequent studies have shown the positive impact of interruptions. Salvucci and Bogunovich (2010) found that when their primary task required participants to attend to an e-mail customer-support task and the interrupting task involved an IM chat, interruptions during higher workloads were more disruptive than interruptions during lower cognitive workloads. However, during higher mental workloads participants switched only $6 \%$ of the time to the interrupting task, while they switched $94 \%$ of the time during lower mental workloads. Their results suggest that interruptions can be delayed during a high cognitive load until the mental workload of the primary task has been minimized.

\section{Metacognition}

As further support for peoples' ability to delay interruptions, Wijekumar and Meidinger (2005) examined the effects of IM interruptions in a programming course as a function of "metacognition." Metacognition is defined as being aware of one's own mental processes or, as suggested by Hacker, Dunlosky, and Graesser (1998) “knowledge of one's knowledge, processes, and cognitive and affective states; and the ability to consciously and deliberately monitor and regulate one's knowledge, processes and cognitive and affective states" (p. 11). According to Bowler (2010), metacognition involves knowing what tasks are easy or difficult for a person, knowing which learning strategies work better in which situations and monitoring and self-regulation of the knowledge and learning process. The importance of metacognitive control in a high-tech learning environment was shown in Wijekumar and Medinger's (2005) study in which students worked on programming exercises while they were allowed to use IM on their desktop computers. Students with more metacognitive skills typically turned off the sounds on their IM and only responded to the interruptions when they had a break. Those with lower metacognitive skills allowed themselves to be interrupted by the IMs. Garret and Danziger (2008) suggested other key ways that people manage IM interruptions. According to the authors, other than IM providing a means of gaining task relevant information rapidly, IM provides a relatively unobtrusive way to test availability. Thus the sender knows that the recipient can ignore or dismiss the IM notification easily or can provide a clear indication of status quickly (e.g., "I'm busy right now and away from my computer."). These interruption managing (metacognitive) skills could also transfer to those who encounter interruptions such as text messaging in classrooms.

\section{Unified Theory of the Multitasking Continuum}

Salvucci, Taatgen and Borst (2009) presented the Unified Theory of the Multitasking Continuum (expanded in Salvucci and Taatgen, 2011) to explain task switching behaviors ranging from concurrent multitasking (e.g., listening and note-taking) requiring near simultaneous processing to sequential multitasking (e.g., writing a paper and reading an email) which allow more time (and control) between 
switches. The crux of the model is based on ACT-R architecture (Anderson, 2007) which posits that information is processed by relatively independent but interacting modules including: (a) a declarative memory module that handles factual knowledge, task instructions and episodic information; (b) a goal module which tracks progress; (c) a problem representation module which contains the information derived during learning that may be needed later in the process; and (d) a procedural module that connects all of the modules together and monitors the flow of information between modules. In ACT-R, all modules can work separately at the same time but each module can only work on a single task at a time. The second part of Salvucci et al.'s theory involves Threaded Cognition Theory (Salvucci \& Taatgen, 2008) which allows for multiple tasks to be performed concurrently. This theory explains how different tasks compete for resources (modules) and interfere with each other to the extent that they share needed resources. If two tasks are similar and/or require complex problem representation and/or require use of the same module at the same time, threaded cognition theory predicts that one thread must wait its turn to use necessary resources or modules which would slow processing.

The final part of Salvucci et al.'s (2009) theory, necessary for handling sequential multitasking, is Memory for Goal Theory (Altmann \& Trafton, 2002), which explains how during an opportunity or requirement to multitask, the new task goal must be activated above the old task goal which then begins to lose activation and fade away. This means that when the interruptive task is completed the original task will take more time to reactivate and result in additional time to complete than if it were attempted without interruption. Salvucci et al. (2009) have applied their model successfully to a variety of external and internal (self-generated) interruptions. In the current study receiving a text message contains both an external interruption (auditory, visual or kinesthetic vibration) and an internal interruption (the decision when to read and respond to the message).
In the this study, students in a classroom situation were sent zero, four, or eight text messages during a 30-minute videotaped lecture to which participants were asked to respond as promptly as possible. Based on Salvucci's Unified Theory of the Multitasking Continuum, Hypothesis 1 predicts that the more texts that the learners had to read and respond to, the lower their memory recall. However, based on the dissimilarity between the videotaped lecture material and the text message content (e.g., What was the last movie you saw and what is your favorite movie?), it was predicted, based on the lack of overlap in shared resources, that this disruption should be minimal. Although participants were asked to respond "promptly" no constraints were set on exactly when they chose to read the text or to respond to the text. Based on the metacognition theory as well as the Unified Theory of the Multitasking Continuum, Hypothesis 2 predicts that those who waited to read a text or respond to a text interruption until a time when memory and attention to the lecture was not deemed as important-presumably demonstrating better metacognition and lower need for memory resources-would produce better memory recall scores than who responded immediately and did not wait for an appropriate time to self-interrupt.

\section{Methods}

\section{Participants}

A total of 185 college students in four undergraduate psychology courses participated in this study. All participants were given course extra credit. Participants included $80 \%$ females and averaged 25 years of age (range: 18 to 66 with $83 \%$ Net Geners born between 1980 and 1989 distributed evenly across groups). The participants' self-reported average GPA was 3.06 and their self-reported current course grades were primarily "As" (57\%) and "Bs" $(47 \%)$ 


\section{Materials and Procedure}

Participants received a form one week before the study providing informed consent and requesting their cell phone number, their carrier, their typical monthly texting behavior, and permission to text them during the class period. Participants were told that they were to view a videotaped lecture relevant to the course and during the lecture some would receive text messages from the investigator. Participants were asked upon receiving the text messages to respond as promptly as possible. To control for other confounding interruptions, participants were asked to place their cell phone on their desk on the vibrate setting along with paper and pen to take lecture notes. Immediately after the videotaped lecture was complete, participants were given the paper-and-pencil memory recall test.

Each class was shown a 30-minute videotaped lecture on life-span development and participants were informed that they would be tested on the material following the lecture. Videotaped presentation, typically used in each course, was selected to maximize the ability to time text message delivery to lecture content; overall, $79 \%$ of the participants rated the videotape as important to their overall grade and $97 \%$ rated it as interesting. An 18-item exam was developed with questions covering material from the entire 30-minute period. Eight prearranged text messages were developed to elicit multiple-word responses from the participants including: "Why did you choose your major?" "If you won $\$ 100,000$ in the lottery, what would you do with the money?" and "What was the last movie you saw and what is your favorite movie?" The text messages were timed to arrive at the same time that the videotaped lecture covered material that was included on the posttest ${ }^{1}$.

\footnotetext{
${ }^{1}$ A pilot test determined that the only way to ensure close to immediate text message delivery was to send it from the same mobile phone carrier as the receiver's mobile phone carrier. Five student research assistants, each using a cell phone with a different major mobile phone carrier, assisted the investigator in sending and receiving text messages during the videotaped lecture. Based on the information collected prior to the study, senders were matched to receivers on the basis of cell phone carrier. Following the posttest, participants consulted their phones and reported the exact time each text message was received.
}

Each classroom was randomly divided into three groups. One third received no text message interruptions, one third received four text message interruptions at timed intervals throughout the videotaped lecture and the final third received the same four text messages plus an additional four text message interruptions spread evenly throughout the lecture but timed to coincide with videotaped lecture content that was assessed on the posttest.

Following the posttest, participants were asked to list information about text messages received by the investigator including exact time received, whether a response was sent and the time it was sent, and the number of words in that response. In addition, participants noted personal text messages they received during the videotaped lecture including the time received, whether a response was made to that message and the time it was sent, and the number of words in the text both received and sent. Participants were also asked questions about their typical texting behaviors in the classroom, and their attitudes about whether it was acceptable to text during class and whether texting during lectures was harmful to their ability to learn the material.

\section{Results}

\section{Group Composition}

Participants were sent zero, four, or eight text messages from the investigators. However, some participants did not receive every text message and, as part of the posttest survey, participants indicated that they had received - and often responded toadditional text messages from people other than the investigators. In fact, during the 30-minute videotaped lecture, participants received an average of between one and two additional texts each $(M=$ $1.41 ; S D=2.59$ ) with $64 \%$ receiving no texts and the other $36 \%$ averaging 3.90 text messages $(S D=$ 3.00). Accordi-ngly, the total number of texts received and sent were tallied and participants were placed into the following groups: No/Low Texting 
Interruption group ( $\mathrm{n}=44$; received plus sent between zero and seven texts; Mean text messages 1.61; $M d n=0)$, Moderate Texting Interruption group ( $\mathrm{n}=76 ; 8-15$ texts; $M=10.09 ; M d n=8)$, and High Interruption Text group $(\mathrm{n}=65 ; 16$ or more texts; $M=19.22 ; M d n=16$ ). Overall, $79 \%$ of the sample remained in their original group.

\section{Attitudes Toward Texting in Class}

Participants were asked several questions concerning their attitudes toward texting during a course lecture. While $75 \%$ of the participants agreed that receiving and sending texts ruins one's ability to learn from a lecture, $40 \%$ of the sample agreed it was acceptable to text during a lecture. In addition, only $18 \%$ of the sample claimed they never responded to a text in class and a most stated that they responded if they received a text from a friend $(67 \%)$ or family member $(75 \%)$ during class. There were no differences in these responses across texting groups.

\section{Typical Texting Behavior}

Participants were asked about the number of texts both sent and received during a typical month. Overall, participants received and sent an average of 1,513 texts per month $(S D=967.00)$. The data, however, were positively skewed (skewness $=4.60$ ) and were truncated at three standard deviations above the mean. These data were then partitioned into thirds and a group comparison revealed a statistically significant difference between groups with the majority of the No/Low Texting Interruption group in the lower third of monthly texting, the Moderate Texting Interruption group showing an even distribution of monthly texting, and the High Texting Interruption group's typical texting being predominantly in the top two monthly texting groups $\left[\chi^{2}(4\right.$, $N=181)=12.43, p<.05]$. Based on these results, the monthly texting behavior was included as a vari- able in the test of Hypothesis 1. No other demographic variables, including age, gender, grade point average, and ethnic background, were correlated with the test score nor showed differences between groups.

\section{Hypothesis 1}

Hypothesis 1 predicted that the more text message interruptions the participant received the worse they would perform on the posttest. The hypothesis was tested with a 3 (text interruption group) $\mathrm{x} 3$ (monthly texting practices groups) ANOVA and showed that the only significant difference was between texting interruption groups $[F(2,182)=$ $3.21, p<.05]$ and that difference had a small effect size (partial $\eta^{2}=.034$ ) according to Cohen (1988). A post hoc Tukey B Test showed that the High Text Interruption group $[M=11.71$ (65\% of the total possible on the test); $S D=3.45$ ] performed significantly worse than the No/Low Texting Interruption group $[M=12.95(72 \%) ; S D=2.01]$ with the Moderate Texting Interruption group $[M=12.58$ $(70 \%) ; S D=2.28$ ] not significantly different from either the No/Low Texting Interruption group or the High Texting Interruption group. Overall, the No/Low Texting Interruption group performed $10.6 \%$ better than the High Texting Interruption group.

The impact of texting behavior was also examined in terms of the amount of words sent and received with a prediction that those participants who sent and received more words (requiring more cognitive workload and more use of all resources in the Unified Theory of the Multitasking Continuum) would perform worse on the posttest. First, a comparison showed that the average number of words received and sent per text was constant between groups, averaging 9.22 words per text sent and received $[F(2,153)=2.13, p>.05]$ as was the average number of words sent $[M=9.26 ; F(2,147)=$ $0.23, p>.05]$ and the average number of words received $[M=9.42 ; F(2,154)=1.77, p>.05]$. A 
correlation analysis revealed that the posttest score was significantly negatively related to total words received $(r=-.158, p<.05)$ and total number of words received and sent $(r=-.125, p<.05)$ while the total words sent was also negatively correlated with posttest score but not statistically significant $(r=-.082, p>.05)$.

\section{Hypothesis 2}

To maximally disrupt learning, text messages were timed to coincide with the videotaped lecture presented material that was included on the posttest and participants were asked to respond promptly to the text messages. Since participants noted the exact time a text was received and their response was sent, the time elapsed between the presentation of a test fact from the videotape and the receipt of and response to a text message was calculated for each text message received or sent. Due to the nature of the videotaped lecture, which often took up to one minute or more to present information that was on the posttest, the calculations for lag between tested lecture material and message receipt and response were made in minute-by-minute increments. For example, suppose the videotaped lecture contained material that was on the posttest at two minutes and 30 seconds from the start of the lecture. If the message was received at, say, two minutes and $45 \mathrm{sec}-$ onds from the start of the videotaped lecture and a response sent at three minutes and 45 seconds then that message would be considered received $15 \mathrm{sec}-$ onds following the videotaped material (or within one minute) and a response sent one minute and 15 seconds following the videotaped material (or between one and two minutes). Figure 1 displays the percentage correct for each test question that was interrupted by a text message under two conditions: (1) the time between when the to-be-tested material appeared on the videotaped lecture and receipt of a text message and (2) the time between the tested material appearing on the videotaped lecture and sending a text message response. The percentages correct for posttest questions are plotted in terms of minutes following the tested videotaped material that a text message was received or sent. It is important to note that the experimental manipulation involved the participants receiving a text message effectively during the lecture material presentation, which would nearly always be included in the 0 to 60 second time frame unless the text message delivery was delayed. In addition, participants were told to respond promptly to the text message but examination of the times that they received a text message and sent a response varied from a few seconds to several minutes. Figure 1 includes all text messages for all participants since no between group differences were found.

Although only suggestive, Figure 1 shows two interesting trends. First, text messages received within the first three to four minutes following tested material showed a consistent $71 \%$ to $78 \%$ correct answers while messages received more than four minutes after tested material demonstrated more than $90 \%$ correct answers. Second, for texts sent by the participants, performance ranged between $70 \%$ and $76 \%$ when that response was made within four to five minutes following the tested material and ballooned to $85 \%$ when the participants waited for more than five minutes to respond to a text message.

\section{Discussion}

The college classroom is home to young Net Generation adults who have been involved in technology and media from a very early age. They are accustomed to multitasking and, therefore, experience a daily spate of interruptions. In addition, they are continually communicating electronically, primarily through sending and receiving text messages and other digital messages. In the classroom, this could be a problem as students continously check their cell phones for messages and, in general, respond to those messages as soon as they arrive. The present study examined the impact of classroom texting on learning and retention of lecture material. 
Figure 1. Percentage correct on memory recall posttest by the time a text message was received or by the time a text message response was sent as a function of the time information for the most recent posttest question appeared on the videotaped lecture

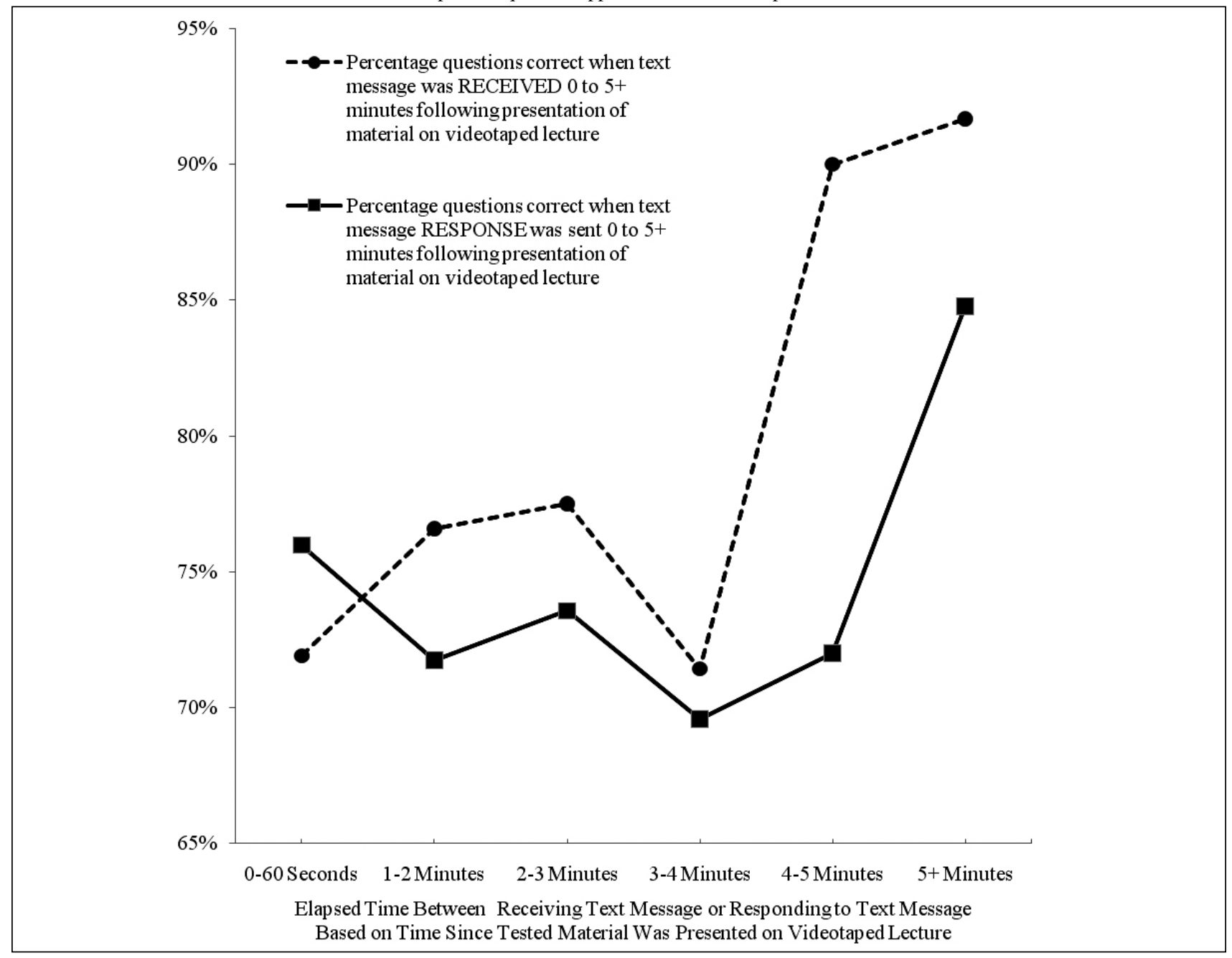

In four university classrooms, students were sent zero, four, or eight texts during a 30-minute videotaped lecture with the text messages sent to coincide with the presentation of information that would appear on a posttest immediately following the lecture. Participants were requested to respond promptly to the texts.

Based on the number of texts sent and received including those sent by the investigator and those received from other people, participants were divided into three groups which included a No/Low Texting Interruption group (with more than half receiving no texts), a Moderate Texting Interruption group, and a High Texting Interruption group. Hypothesis 1, based on Salvucci et al.'s (2009) Unified Theory of the Multitasking Continuum, pre- dicted that the more texts that learners had to read and respond to, the lower their memory scores on the posttest. However, the Threaded Cognition Theory and Memory-for-Goals Theory also predicted that since the text message content had little overlap with the lecture material (and the text message content was really quite innocuous and simple to answer), this memory disruption should be minimal. This hypothesis was supported since only the High Texting Interruption group differed significantly from the No/Low Texting Interruption group and that difference only represented a $10.6 \%$ reduction in memory and a small effect size (Cohen, 1988). This is supported by and validates research by Oulasvirta and Saariluoma (2004) who found that interrupting messages decreased memory accuracy 
by $16 \%$, particularly when the interruptive material was semantically similar to the to-be-learned material. Finally, the significant negative correlations between the total number of words sent and received, and the number of words received but not sent adds further support to the Unified Theory of the Multitasking Continuum. According to this theory, the arrival of a text message would first require an additional thread which would then compete for shared resources with any threads begun by watching to the videotaped lecture material. Second, the text message arrival would deactivate the goal of attending to the videotaped lecture material and, instead, activate attending to answering the questions from the investigator. It is not surprising at the relatively small effect the interruptions had on performance is not surprising given the fact that these questions were unrelated to the lecture material and, by their nature, did not require extensive cognitive workload. Attending to the text message did impact performance, but the impact was quite small due to the minimal nature of the disruptions to the threaded cognitions and the memory for goals.

Participants received text messages throughout the videotaped lecture. For the High Text group those eight text messages occurred during material to be tested while the two other groups either received no texts to disrupt learning or received half the number of texts as the High Text group. Many participants also received texts from other people during the lecture. Although participants were instructed to respond to the text messages promptly, some, as seen in Figure 1, chose not to do so. In addition, when texts from toher people arrived, participants could choose when to respond. A detailed analysis demonstrated that those participants who chose to wait more than four to five minutes to respond to a text message did substantially better than those who responded more rapidly. Although these data are merely suggestive, this lends some support to the idea that participants may have consciously employed metacognitive strategies, perhaps indicating, as shown in an IM study by Wijekumar and Meidinger (2005), that participants were aware that if they responded to the interruption during lecture periods that were more likely to contain testable information they would not learn the material as well as if they waited for a time when the lecture material was less likely to be on the exam.

Overall, this study supports the idea that classroom texting may not be as interfering as assumed by teachers. Even when participants were inundated with text messages-receiving and sending 16 or more texts in a 30-minute period-their performance was only slightly (albeit significantly) worse than those receiving no texts or a few texts. The fact that the Moderate Texting Interruption group did no worse than the No/Low Texting Interruption group lends further support to the minimal interference of classroom texting. However, it must be noted that a $10.6 \%$ difference between the group receiving the most text messages and the group receiving the least text messages is equivalent to one letter grade.

It is important to note, however, the prevalence of texting in the typical university classroom. As Tindell and Bohlander (2011) reported, nearly all students have sent or received a text message in class. During this short 30-minute videotaped lecture $36 \%$ of the participants received at least one text message - and averaged nearly four text messages-in addition to those sent by the experimenters. This confirms that rampant texting in class may be a problem for some students and this is an issue that must be evaluated with each teacher and each classroom.

\section{Educational Implications}

The results of this study will undoubtedly baffle teachers and parents who insist that multitasking in the classroom and at home is extremely harmful to comprehension. Even with constant texting the High Text group only performed just under $11 \%$ worse than the group with no texts. Surprisingly, the Moderate Text group, which sent and received 8 texts in 30 minutes, did not do any worse than those who got essentially no texts. In defense of teens' and 
young adults' propensity to multitask at all times with multiple forms of media, Rosen et al. (2010) suggests that teachers and parents allow children, teens and young adults to multitask, particularly when the task demands of the secondary task are low (e.g., familiar music) or when the tasks require different sensory modalities (music vs. reading).

In the classroom, however, the problems are magnified. Students who constantly check their technology for text messages, Facebook updates, etc. can do so surreptitiously since research has shown that $42 \%$ of teens can text blindfolded (Harris Interactive, 2008). Some schools have opted to require all cell phones to be turned off or even, in the extreme, deposited in a box by the classroom door. The problem is that just because the student's technology is "out of sight" it is not "out of mind." For example, Dumontheil, Gilbert, Burgess, and Otten (2010) found no neurological differences between externally driven task switching (e.g., responding to a text message beep) and internally driven switches (e.g., "thinking about" a text message). This study, plus other neurological research, suggests that keeping technology away from students will not remove it from the students' brain activation. In fact, Foerde, Knowlton, and Poldrack (2006) found that during task switching there is a shift in neural activity from the hippocampus, which is the seat of thought and memory to the striatum, which is a brain region associated more with rote or habitual learning. If students are continually internally task switching then it is entirely possible that even during periods where they are supposed to be paying attention, they may be doing so primarily using a brain area that is not conducive to analytical learning.

One strategy which may help this process is what the authors refer to as a "technology break." Similar to a coffee break where a person is feeling low on energy and needs to get a dose of caffeine to feel more motivated and energized, a technology break can supply the student the knowledge that within a certain time period a break will be available to check in with their connected world. On a neurological level this process should promote the student pro- cessing information more in the hippocampus, which will lead to better understanding and memory for the course information. Trials of this strategy are being implemented with good anecdotal results. For example, in one high school, students are told that every 15 minutes they will get a one to two minute break (depending on the teacher) to check their e-mail, text messages, Facebook posts using any approved technology (the school has a laptop program for all students and $96 \%$ of the students text). In a typical 45 minute class this amounts to two short tech breaks and rather than a waste of two to four minutes of learning, teachers are reporting that the students are more alert during the 15-minute teaching time.

Along these lines we must also consider the interesting results displayed in Figure 1 where students who waited a period of time to either open and read a text or respond to a text performed better on the test. This suggests that we should be teaching our students metacognitive strategies that focus on when it is appropriate to take a break and when it is important to focus without distractions. In one study currently underway by the authors (Rosen, Carrier, \& Cheever, 2011), high school and university students were observed for 15 minutes (the same amount of time we recommend for focusing before taking a tech break) while they studied in their natural environments (usually their bedroom or a den area). Their expected grade on the material as well as their grade point average were predicted by five variables: how often they stayed "on task" rather than switching to another task (almost always technology-based), whether they had strategies for studying, their preference for task switching, the total media hours per day and whether they checked their Facebook page once during the study period. If these students applied a metacognitive strategy of staying on task for 15 minutes, learning not to embrace task switching as a normal part of studying and not switching to their Facebook page while studying, they would perform better in school. Perhaps knowing that after the 15-minute study period they could switch to check Facebook or other technology learning might be enhanced. 
In a typical classroom setting, requiring students who multitask or task switch when they are not in school to sit and unitask can and will lead to boredom and lack of attention or, as some teachers have discovered, students surreptitiously using their cell phones from their laps. Rosen et al. (2010) conclude, "The bottom line is that our students are multitasking and we cannot stop them without placing them in a boring, unmotivating environment. The trick is to develop educational models that allow for appropriate multitasking and that improve learning" (p. 95).

\section{Limitations}

There are several limitations to this study including an inability to precisely establish an exact time when relevant, tested material was on the videotape lecture since that material spanned from seconds to a minute or more. This is inherent in a real classroom environment and could be controlled by presenting fact-based information that is stated in seconds during the lecture although this would distort the typical lecture style. In addition, the fact that participants received and responded to texts from other people may have interfered with their responses to texts sent by the investigators; however, the timing of those texts was recorded and synchronized with the videotaped lecture and they represented only a small percentage of overall texts. The fact that the group that was supposed to receive no texts did receive an occasional text message from someone else presented that group with a source of interference. Given that these occurrences were raremore than half this group received no texts but some participants in this group did send and/or receive as many as seven texts - it may be helpful to control outside texting. This could be accomplished by replacing texting to cell phones with a more controlled use of classroom response systems as interruption tools (Kay \& LeSage, 2009). Another limitation involved with the texting environment is the interruptive quality of the text messages themselves. Participants were asked to have their phones on vibrate and close at hand, but it may be the case that the constant vibrations were disruptive to them (or other students in the classroom) and reduced their learning ability. The fact that the average score on the exam was around $70 \%$ and the scores were equally distributed within each group, it is unlikely that the vibrating sounds differentially affected the participants in any particular group.

This study was done in a university classroom. Given the excessive texting data for teens, it would be important to replicate the results in a high school classroom. Finally, it would be important to pilot test both teaching students metacognitive strategies for when to focus and when it is not harmful to task switch, coupled with the implementation of tech breaks, to determine if these teaching strategies do indeed improve classroom performance.

\section{References}

Altmann, E. M. \& Trafton, J. G. (2002). Memory for goals: An activation-based model. Cognitive Science, 26, 39-83.

Altmann, E. M. \& Trafton, J. G. (2004). Task interruption: Resumption lag and the role of cues. NY: Erlbaum. Proceedings of the 26th annual conference of the Cognitive Science Society.

Anderson, J. R. (2007). How can the human mind occur in the physical universe? New York: Oxford University Press.

Benbunan-Fich, R. \& Truman, G. E. (2009). Multitasking with laptops during meetings. Communications of the ACM, 52, 139-141.

Bowler, L. (2010). The self-regulation of curiosity and interest during the information search process of adolescent students. Journal of the American Society for Information Science and Technology, 61, 1332-1344.

Bowman, L. L., Levine, L. E., Waite, B. M., \& Gendron, M., (2010) Can students really multitask? An experimental study of instant messaging while reading. Computers \& Education, 54, 927931. 
Carrier, L. M., Cheever, N. A., Rosen, L. D., Benitez, S., \& Chang, J. (2009). Multitasking across generations: Multitasking choices and difficulty ratings in three generations of Americans. Computers in Human Behavior, 25, 483-489.

Cohen, J. (1988). Statistical power analysis for the behavioral sciences (2nd ed.). Mahwah, NJ: Lawrence Erlbaum.

Czerwinski, M., Horvitz, E., \& Wilhite, S. (2004). A diary study of task switching and interruptions. In Proceedings of the ACM Conference on Human Factors in Computing Systems (pp. 175-182). New York: ACM.

Dumontheir, I., Gilbert, S. J., Burgess, P. W., \& Otten, L. J. (2010). Neural correlates of task and source switching: Similar or different? Biological Psychology, 83, 239-249.

Foerde, K., Knowlton, B. J., \& Poldrack, R. A. (2006). Modulation of competing memory systems by distraction. Proceedings of the National Academy of Sciences of the USA, 103, 11778-11783.

Fox, A. B., Rosen, J., \& Crawford, M. (2009). Distractions, distractions: Does instant messaging affect college students ' performance on a concurrent reading task? CyberPsychology, 12, 51-53.

Fried, C. B. (2008). In-class laptop use and its effects on student learning. Computers \& Education, 50, 906-914.

Garrett, R. K. \& Danziger, J. N. (2008). IM= Interruption management? Instant messaging and disruption in the workplace. Journal of Computer-Mediated Communication, 13, 23-42.

Gonzalez, V. M. \& Mark, G. (2004). Constant, constant, multitasking craziness: Managing multiple working spheres. Proceedings of CHI '04, pp. 113-120.

Hacker, D. J., Dunlosky, J. and Graesser, A. C. (1998). Metacognition in educational theory and practice. Mahwah, NJ: Erlbaum.

Harris Interactive (2008). A Generation Unplugged. Research report retrieved from http://files.ctia. org/pdf/HI_TeenMobileStudy_ResearchReport.pdf.

Jackson, T., Dawson, R. \& Wilson, D. (2003). Reducing the effect of email interruption on employ- ees. International Journal of Information Management, 23, 55-65.

Judd, T. \& Kennedy, G. (2011). Measurement and evidence of computer-based task switching and multitasking by 'Net Generation' students. Computers \& Education, 56, 625-631.

Kay, R. H. \& LeSage, A. (2009). The benefits and challenges of using audience response systems: A review of the literature. Computers \& Education, 53, 819-827.

Lenhart, A. (2010). Teens, cell phones and texting: Text messaging becomes centerpiece communication. Washington, DC: Pew Internet \& American Life Project. Retrieved from http://pewresearch. org/pubs/1572/teens-cell-phones-text-messages.

Lenhart, A., Ling, R., Campbell, S., \& Purcell, K., (2010, April 20). Teens and mobile phones: Text messaging explodes as teens embrace it as the centerpiece of their communication strategies with friends. Washington, DC: Pew Internet \& American Life Project. Retrieved from http:// www.pewinternet.org/Re ports/2010/Teens-andMobile-Phones.aspx.

Mark, G., Gudith, D., \& Klocke, U. (2008). The cost of interrupted work: More speed and stress. In Computer-Human Interactions (CHI), Florence, Italy: ACM, 107-110.

Monk, C. A., Trafton, J. G., \& Boehm-Davis, D. A. (2008). The effect of interruption duration and demand on resuming suspended goals. Journal of Experimental Psychology: Applied, 14, 299-313.

Nielsen Company (2011). State of the media 2010: U.S. audiences \& devices. Retrieved from http://blog.nielsen.com/nielsenwire/wpcontent/uploads/2011/01/nielsen-media-factsheet-jan-11.pdf.

Ophir, E., Nass, C.I. \& Wagner, A. D. (2009). Cognitive control in media multitaskers. Proceedings of the National Academy of Sciences, 106, 1558315587.

Oulasvirta, A. \& Saariluoma, P. (2004). Long-term working memory and interrupting messages in human-computer interaction. Behaviour \& Information Technology, 23, 53-64. 
Oulasvirta, A. \& Saariluoma, P. (2006). Surviving task interruptions: Investigating the implications of long-term working memory theory. International Journal of Human-Computer Studies, 64, 941-961.

Parnin, C. \& Rugaber, S. (2009). Resumption strategies for interrupted programming tasks. Software Quality Journal, 19, 5-34.

Ratwani, R. M., Andrews, A., Sousk, J., Trafton, G. (2008). The effect of interruption modality on primary task resumption. In Proceedings of the Human Factors and Ergonomics Society 52 Annual Meeting, (pp. 372-375). Santa Monica, CA: Human Factors and Ergonomics Society.

Rosen, L. D. (2007). Me, MySpace, and I: Parenting the Net Generation. NY: Palgrave Macmillan.

Rosen, L.D., Carrier, L. M., \& Cheever, N. A. (2010). Rewired: Understanding the iGeneration and the Way They Learn. NY: Palgrave Macmillan.

Rosen, L.D., Carrier, L. M., \& Cheever, N. A. (2011). How do today's students task switch while studying? Lessons for technological distractions and metacognitive strategies for learning. Unpublished manuscript.

Salvucci, D. D. \& Bogunovich, P., (2010). Multitasking and monotasking: The effects of mental workload on deferred task interruptions. In Proceedings of the SIGCHI Conference on
Human Factors in Computing Systems: CHI 2010. New York: ACM Press.

Salvucci, D. D. \& Taatgen, N. A. (2008). Threaded cognition: An integrated theory of concurrent multitasking. Psychological Review, 115, 101130.

Salvucci, D. D. \& Taatgen, N. A. (2011). The Multitasking Mind. New York: Oxford University Press.

Salvucci, D. D., Taatgen, N.A., \& Borst, J. P. (2009). Toward a unified theory of the multitasking continuum: From concurrent performance to task switching, interruption, and resumption. In Proceedings of the SIGCHI Conference on Human Factors in Computing Systems: CHI 2009. New York: ACM Press, pp., 1819-1828.

Tindell D. R. \& Bohlander, R. W. (2011). The use and abuse of cell phones and text messaging in the classroom: A survey of college students. Manuscript submitted for publication.

Wijekumar, K. \& Meidinger, P. (2005). Interrupted cognition in an undergraduate programming course. Proceedings of the American Society for Information Science and Technology, 42(1).

Zickuhr, K. (2011). Generations and their gadgets. Washington, DC: Pew Internet \& American Life Project. Retrieved from http://www.pewinternet. org/ /media//Files/Reports/2011/PIP_Generation s_and_Gadgets.pdf

Manuscrito recibido: 23/03/2011

Revisión recibida: 12/04/2011

Manuscrito aceptado: 14/04/2011 